\title{
A Study on Change in the Attitude of Students towards English Language Learning
}

\author{
C. Vijaya Bhaskar ${ }^{1} \&$ S. Soundiraraj ${ }^{2}$ \\ ${ }^{1}$ Teaching Fellow \& Research Scholar, Department of English, College of Engineering, Anna University, India \\ ${ }^{2}$ Associate Professor, Department of English, College of Engineering, Anna University, India \\ Correspondence: C. Vijaya Bhaskar, Department of English, College of Engineering, Anna University, Chennai - \\ 600 025, Tamil Nadu, India. Tel: 979-106-6107. E-mail: vijayouhyd@gmail.com
}

\author{
Received: December 7, 2012 Accepted: April 4, 2013 Online Published: April 12, 2013 \\ doi:10.5539/elt.v6n5p111 URL: http://dx.doi.org/10.5539/elt.v6n5p111
}

\begin{abstract}
The purpose of this paper is to find out whether there is any change in the attitude of students towards English Language Learning (ELL) when they come for college education after completing the school education. The transformation in the attitude of students from school to college was examined in terms of marks, interest towards English language, self- motivation to learn the language, participation in the class, understanding the importance of English in securing a job and learner-centred language teaching methods that ensure more freedom to the learners. About 52 first year Mechanical Engineering students from Tamil medium stream took part in this research. To examine their shift in attitude towards ELL, an attitude questionnaire was administered and a semi-structured interview was conducted. The findings of the study indicated that there was a significant shift in their attitude towards ELL at their college level.
\end{abstract}

Keywords: attitude, English Language Learning, college level, school level

\section{Introduction}

Learning English language is considered as an important aspect at every stage of educational process. In general, the two different levels, both school and college, where English is taught to students in different learning situations, seem to serve two different ends. The language taught and learnt at these two levels is based on different needs and factors. For instance in schools, the language teaching focuses on factors like marks, completion of syllabus and practice or coaching for students to write examinations. In colleges, the language teaching lays emphasis on soft skills, communication skills and employability skills to meet the requirements of employers from companies and industries.

Students emerging from situations of these kinds as mentioned above, tend to have their own respective attitudes towards ELL. The attitude of students is determined by the impact created by various factors while learning the language. At school level, the attitude of the students towards language learning is different since their mind is preoccupied with examination pattern and marks they score in the examination. But when the same students come to college, with no proper evidence, it cannot be substantiated that they have the same kind of attitude towards language learning as they had in school. At the same time, it cannot be concluded that at college level their attitude will change completely. At college level, it is essential to impart language programmes by realizing the appropriate attitudes perceived by the students as there is a strong correlation between attitude and language learning process. Therefore, it will be immensely useful to know the attitude of the students at college level to plan and implement the language programme successfully.

\section{Literature Review}

Learners need to have positive attitude to acquire high level of proficiency in the target language. While defining 'attitude', Gardner (1985) says: “An individual's attitude is an evaluative reaction to some referent or attitude object on the basis of the individual's beliefs or opinions about the referent". He also adds that it is motivation that lies with attitudes towards other ethnicities and language learning contexts. According to Chapman and McKnight (2002), "Attitude is your general disposition - your mental "starting point" for viewing life and the people and events in it. From your viewpoint, attitude is the way you look at things mentally and it all starts inside your head. For others, your attitude is the overall mood they interpret from what they see you say and do." 
Baker (1988) argues that attitudes are dispositions to approach an object, a person, an institution or an event favourably or unfavourably.

The study on language attitudes was made by Gardner and Lambert (1972). They studied the interrelationships of different types of attitudes, and emphasized the significance of group-specific ones - the attitude learners possess towards the speakers of the language they intend to learn. It is understood that learners possessing positive attitudes towards people who speak the language and the language itself can help them to learn the target language. It seems that second language learners benefit a lot when they possess positive attitudes.

Ellis (1994) mentions that positive attitudes towards the L2 and its speakers can be expected to enhance learning while negative attitudes impede it. Learner attitudes have an influence on the level of L2 proficiency achieved by individual learners. Thus, learners with positive attitudes become successful in achieving their goals whereas those with negative attitudes find it difficult to acquire the expected level of proficiency in English. Besides, even the negative attitudes of the students can be changed by adopting apt methods and materials to help students acquire favourable attitude towards the target language and the culture of the native speakers of that language (Brown 2000).

Doughty and Long (2003) mention that the second language acquisition depends on a modification of attitudes, knowledge, and behaviour towards the members of the target language group. A positive change in the attitude of students towards the native speakers is essential for the acquisition of target language.

A study by Akram, Aatika and Rabia Yasmeen (2011) confirms that people of Faisalabad have more positive attitudes towards English than Punjabi language as English is associated with the favourable aspects like job opportunities, status, prestige and the support from the government. Because of these favourable features, most of the people show positive attitude towards English language and learning. Another study by Mostafizar Rahman (2008) proves that attitude of Malaysian undergraduates have strong positive attitude towards English. The respondents in this study feel that English was essential for job placement. They also mention that English should be the medium of instruction in schools and colleges in view of employment opportunities.

The formation of attitude of students depends on their level of exposure to variety of sources like newspapers, magazines, television, movies and lectures in class. The major features that may have a role in attitude formation are family (emotionally toned ideas very early in life), school (fostering attitudes to respect for law and order) and the press (powerful tools for creating and controlling attitudes). In this regard, it is considered that the educational context in Tamil Nadu, a southern state of India gives time and space for the students to have an exposure to the language. The question is whether school education fosters positive attitude among students towards ELL. The next question is whether there is any change in their attitude towards ELL especially after their admission in the college. Therefore, the researcher decides to focus on this particular issue and frame the main question: Do the students change their attitude towards ELL when they come for college education?

\section{Methodology}

\subsection{Participants and the Setting}

This study was carried out in College of Engineering, Anna University, Chennai. The students who took part in this study were from the first year Mechanical Engineering course, where Tamil, a major regional language is the medium of instruction. All the subjects in this course are exclusively taught through Tamil medium. In addition, Technical English is also offered in view of their needs in job placement. The Tamil medium stream was introduced especially to help students from rural background and make Tamil language as a medium of instruction so that the students can understand the concepts in science and engineering clearly. As the medium of instruction for these students at school level was Tamil, they were quite comfortable with their studies at college level. However the students faced certain difficulties in learning the target language - English. The syllabus, methods of teaching and evaluation system for Technical English in colleges are different when compared with the English course in schools. So, the participants in this study had no clear idea about Technical English when they joined this course and most of them felt it was a new experience.

\subsection{The Instruments}

\subsubsection{Attitude Questionnaire}

This study was based on both quantitative and qualitative data. The researcher collected the quantitative data through a questionnaire given in appendix for assessing the attitude of students towards ELL both at school level and at college level. The questionnaire included 10 items, structured as statements with the options 'Agree' and 'Disagree'. The questionnaire was reviewed by two experts in language teaching before it was distributed to the participants of the study. 


\subsubsection{Semi-Structured Interview}

The qualitative data was obtained through semi-structured interview. It provides a very flexible technique for small-scale research and also allows thematic analysis of the qualitative data. The aim was to get a clear idea about the attitude of students with regard to ELL. Nearly 15 students were randomly selected and interviewed by the researcher. He asked questions related to the students' likes and dislikes about language learning, their experience about the technical English course, opinions they perceived about the language before and after they had joined the college and the difficulties they faced in learning the language. Through better rapport between the students and researcher, the objective of the interview was achieved. The interviews with the participants were recorded by the researcher and were later transcribed for analysis.

\section{Results and Discussion Based on Questionnaires}

This section deals with the responses of the students collected through questionnaires and presents the discussion based on the results.

Table 1. Responses of the students

\begin{tabular}{llllll}
\hline \multirow{2}{*}{ S1. No } & Statements (in the form of phrases) & \multicolumn{2}{l}{ School Level } & \multicolumn{2}{l}{ College Level } \\
\cline { 3 - 6 } & $\begin{array}{l}\text { Agree } \\
(\%)\end{array}$ & $\begin{array}{l}\text { Disagree } \\
(\%)\end{array}$ & $\begin{array}{l}\text { Agree } \\
(\%)\end{array}$ & $\begin{array}{l}\text { Disagree } \\
(\%)\end{array}$ \\
\hline 1 & Reaction towards marks & 76.9 & 23 & 28 & 72 \\
\hline 2 & Interest in learning the language & 71.15 & 28.84 & 86.53 & 13.46 \\
\hline 3 & Importance of four language skills & 48 & 52 & 98.2 & 1.98 \\
\hline 4 & Teaching- learning environment & 69.23 & 30.76 & 96.15 & 3.84 \\
\hline 5 & Students as active participants & 50 & 50 & 92.30 & 7.6 \\
\hline 6 & $\begin{array}{l}\text { Importance and role of English } \\
\text { language in securing a job }\end{array}$ & 61.53 & 38.46 & 86.53 & 13.46 \\
\hline 7 & $\begin{array}{l}\text { Impact of audio-visual equipment on } \\
\text { students }\end{array}$ & 38.46 & 61.53 & 90.38 & 9.61 \\
\hline 8 & $\begin{array}{l}\text { Student-centred method that ensures } \\
\text { freedom to explore the language }\end{array}$ & 48.07 & 51.92 & 86.53 & 13.46 \\
\hline 9 & Activities to develop speaking skills & 61.53 & 38.46 & 94.23 & 5.76 \\
\hline 10 & $\begin{array}{l}\text { Encouragement to read English } \\
\text { magazines and newspapers }\end{array}$ & 48.07 & 51.92 & 82.69 & 17.30 \\
\hline
\end{tabular}

\subsection{Reaction towards Marks}

Statement-1 is concerned with the students' opinion about how they perceived English language learning both at school level and at college level with regard to marks. The table given above indicates noticeable details about their attitude towards marks. Nearly $77 \%$ of the students agree with the view that they learnt English language only for marks at school level. Only $28 \%$ of the students say that they learnt English language only to secure high marks even at college level. It is clear that students at school level learnt English language primarily for marks. But at the same time, majority of the students changed their attitude towards marks after they had joined for college education. They confirm that they did not learn English for marks alone. This shows that these students changed their attitude as a result of their awareness about the requirements of job placement.

\subsection{Interest in Learning the Language}

The second statement in the questionnaire was to get information about their interest in learning the language. About 86.53 percent of the students opine that their interest in learning the language increased to a greater extent at college level because of the creative methods used by teachers. However, 71 percent of the students say that they were also interested in learning the language at school level. This shows that creativity in language teaching is the major motivating factor for more number of students showing interest in language learning at college level.

\subsection{Importance of Four Language Skills}

In response to statement-3, a large number of students (98\%) believe that teachers of English lay emphasis on four language skills in colleges, whereas only $48 \%$ of them agree with the same in schools. The amount of thrust at college level on four language skills gradually increased their motivation level in learning the language. It is 
understood that the attitude of the students towards the four language skills is positive compared with their attitude towards the same in schools.

\subsection{Teaching - Learning Environment}

The analysis of the responses to the fourth statement indicates a positive attitude from the students at college level since teaching-learning environment helps them acquire language skills from an even better perspective. Around $96 \%$ of the students agree with the view that the teaching-learning environment in colleges played a supportive role in enhancing their language skills. But only 69 percent of the students think that teaching learning environment in schools improved their language learning skills. It is obvious that only at college level, majority of the students have favourable attitude towards teaching learning environment.

\subsection{Students as Active Participants}

In terms of active participation in the class, the results are more positive at college level. About $92 \%$ of the students say that they participated actively in language classes. But at school level only $50 \%$ of the students mention that they were active participants in the class. This reveals that there is a lot of scope for interaction between teachers and students in language classes only at college level.

\subsection{Importance and Role of English Language in Securing a Job}

The responses to the next statement reveal that a large number of students at college level realized the importance and role of English language in securing a job. Around $86 \%$ of the students agreed with this statement positively at college level whereas only $61 \%$ of students were in favour of the statement at school level. It indicates that students, in general, realize the importance of English only in colleges.

\subsection{Impact of Audio-Visual Equipment on Students}

The statement-7 deals with the effect of audio-visual equipment on students in ELL. Around $90 \%$ of the students feel that their language learning got enhanced due the audio-visual equipment used in the classroom at college level. But only $38 \%$ of the students agree with this statement at school level. It is obvious that students' attitude towards the use of audio-visual aids in language learning has changed. It means that the use of audio-visual equipment in language classes has a positive impact on their learning.

\subsection{Freedom to Explore the Language from Students' End}

The statement- 8 is about the students' freedom to learn the language through learner-centred language teaching. Nearly $87 \%$ of the students say that they learnt the language with freedom at college level as the teaching is student-centric. Only 48 percent of the students mention that they had freedom in language learning at school level. It is obvious that language learning in colleges ensure more freedom, which helps them understand the language in full-fledged manner. It is understood that student-centric teaching allows more freedom in learning the language.

\subsection{Activities to Develop Speaking Skills}

The statement - 9 is concerned with activities in developing the speaking skills of the students. Around $94 \%$ of the students agree with the view that activities like role play, group discussion and presentation helped them develop their speaking skills at college level. In contrast, only $62 \%$ of the students believe that these activities helped them develop their speaking skills at school level. Most of the students have changed their attitude towards learning the language because of these activities in colleges.

\subsection{Encouragement to Read English Magazines and Newspapers}

The statement -10 is about whether students are encouraged to read English magazines and newspapers, to listen to English news and to watch programs in English. Around 83\% of the students say that they were encouraged to read English magazines and newspapers at college level. They also confirm that they were motivated to listen to English news and watch programs in English. But only 48\% of the students mention that in schools they were encouraged to get exposure to English by reading magazines and newspapers, listening to English news and watching programs in English. This shows that college environment is more beneficial compared with the kind of encouragement given for exposure to English language in schools.

\section{Results and Discussion Based on Semi-Structured Interview}

The semi-structured interview as a data collecting device used for the study shows how they perceive ELL both at college and school level. The discussion is as follows.

Regarding marks, most of the students say that they learnt English merely for the purpose of scoring high marks. For instance, one of the students participated in this study says: "In my school life, I learnt English language only 
for getting good marks. I worked out old question papers and focussed on high scores, so my mind was preoccupied with marks and question paper pattern."

In response to the question on their interest in learning the language, a couple of students say: “...we memorized essays and paragraphs in schools. We did not care about communication skills and we didn't enjoy learning English in school as we do in college. In colleges, learning English is different and interesting." In addition, another student says: "In school, I learnt English generally with no focus. I did not get a chance to develop my communication skills."

Regarding the question on four language skills, some students say: “...In school, only writing practice was given importance. Other skills like speaking, reading and listening received less attention. Besides, there was a general opinion that writing would help us in examinations."

Related to teaching learning environment, a student says "There are differences between school and college ambience. In school, the classroom environment was in favour of the use of regional language for communication as there was no need to use English. In the college, students from different parts of the state and country come for engineering education and we try to speak in English in the class. In addition, we are encouraged to use English even outside the classroom."

Most of the students mention that they were active participants in the college whereas in school they were passive listeners. For instance, one of the students records his view: “...as various tasks were given in classrooms, I too took part in the tasks and tried to contribute to it...as we were divided into groups, we generated mutual co-ordination among our group members and completed the task."

Regarding the importance of English language in securing a job, many students believe that language teaching at college level should help them improve their communication skills in view of job placements. One of them comments: "...English was only a subject in school...in college it was important for my future because it was useful in getting a good job. I would learn English to get a good job."

Most of them have an opinion that Audio-visual equipment used in classrooms helped them in understanding the concepts clearly. The opinion of a participant is as follows: “...at college, audio and video materials used in the classroom helped us to understand the ideas clearly...Moreover, it generated interest in us towards English language."

The student-centric teaching gives more freedom to students to realize their potential in language learning. Regarding this one of them says: “... we got a lot of opportunities to use English in language class at college level and we used it properly to develop our language skills...initially we hesitated but later we enjoyed students-centric language teaching. In schools, this was missing."

In response to the question on speaking skills, they feel that more importance was given to speaking skills at college level whereas less importance was given to these skills at school level. A couple of students record their views: “...certainly, we picked up speaking skills through activities like 'one minute talk', 'role play' and 'group discussion'. I could see a good change in my speaking skills. In schools, we didn't have activities to develop our speaking skills."

Regarding the encouragement from teachers to read newspapers and listen to English programmes, most of them opine that this sort of motivation from teachers had a positive effect on them. Their views given in the following lines are: "...we were encouraged to read English dailies and listen to English news regularly. This was useful to us in improving our language skills."

\section{Conclusion}

The results from the present study reveal the positive attitudes of the students towards ELL at college level when compared with their attitudes at school level. The change in attitude is clear due to various factors such as the student-centric teaching, teaching based on the requirements of employers and the teaching learning environment in college. The findings prove that there is a positive change in the attitude of students towards language learning. The study suggests that English language teaching in school has to undergo changes to make them good learners. The examination - oriented approach can be given up and more emphasis can be laid on speaking skill activities, use of audio-visual aids, encouragement to make them independent learners and use of innovative teaching methods. In addition, efforts can be taken to make them active participants in language classes. These measures will transform them into good learners. In short, they can become proficient in English when they come for college education if the above discussed positive changes are brought about in English language teaching at school level. In the same way, it can be suggested that at college level, language teaching needs to suit the expectations and the attitude of students for effective teaching learning process. 


\section{References}

Akram, Aatika., \& Rabia Yasmeen. (2011). Attitudes towards English \& Punjabi Language Learning in Faisalabad. Journal of Academic and Applied Studies, 1(4), November 2011, 9-32. Retrieved from www.academians.org

Baker, C. (1988). Key issues in bilingualism and bilingual education. Clevedon, Avon: Multilingual Matters.

Brown, H. (2000). Principles of Language Learning and Teaching. New Jersey: Prentice Hall.

Chapman, Elwood N., \& Mcknight, Wil. (2002). Attitude: Your Most Priceless Possession. Canada: Crisp Publications, Inc.

Ellis, R. (1994). The study of second Language Acquisition. Oxford: Oxford University Press.

Gardner, R. (1985). Social Psychology and Second Language Learning: The Role of Attitudes and Motivation. London, GB: Edward Arnold.

Gardner, R., \& Lambert, W. (1972). Attitudes and Motivations in Second Language Learning. Rowley, Massachusetts: Newbury House.

Doughty, Catherine J., \& Long Michael H. (Eds). (2003). The Handbook of Second Language Acquisition. USA: Blackwell Publishing Ltd.

Rahman, Mostafizar. (2008). Attitudes Towards English Among Malaysian Undergraduates. Language in India. Retrieved from http:/www.languageinindia.com/feb2008/malayenglishattitude.html

\section{Appendix}

\section{Questionnaire - Attitude of Students towards ELL at School Level and College Level}

(Read each statement and put a tick mark to indicate your option)

\begin{tabular}{|c|c|c|c|c|c|}
\hline \multirow[b]{2}{*}{$\begin{array}{l}\text { Sl. } \\
\text { No }\end{array}$} & \multirow[b]{2}{*}{ Statements } & \multicolumn{2}{|c|}{ School Level } & \multicolumn{2}{|c|}{ College Level } \\
\hline & & Agree & Disagree & Agree & Disagree \\
\hline 1 & I learnt English only to secure good marks. & & & & \\
\hline 2 & $\begin{array}{l}\text { English was taught with creativity and it made me show more } \\
\text { interest in the subject. }\end{array}$ & & & & \\
\hline 3 & $\begin{array}{l}\text { The teacher laid emphasis on all four language skills (listening, } \\
\text { speaking, reading and writing). }\end{array}$ & & & & \\
\hline 4 & $\begin{array}{l}\text { The teaching-learning environment was supportive and it } \\
\text { enhanced my language learning. }\end{array}$ & & & & \\
\hline 5 & I was an active participant in the English class. & & & & \\
\hline 6 & $\begin{array}{l}\text { I was aware that proficiency in English was essential in view of } \\
\text { employment opportunities. }\end{array}$ & & & & \\
\hline 7 & $\begin{array}{l}\text { Audio - visual equipment used in the class helped me } \\
\text { understand the concepts clearly. }\end{array}$ & & & & \\
\hline 8 & $\begin{array}{l}\text { Student-centred teaching methods gave me more freedom to } \\
\text { explore the language from my end. }\end{array}$ & & & & \\
\hline 9 & $\begin{array}{l}\text { Activities like role play, group discussion, and presentation were } \\
\text { part of learning modules to develop my speaking skills. }\end{array}$ & & & & \\
\hline 10 & $\begin{array}{l}\text { I was encouraged to read English magazines and newspapers, } \\
\text { listen to English news and watch programs in English. }\end{array}$ & & & & \\
\hline
\end{tabular}

